International Journal of English Literature and Social Sciences
Vol-6, Issue-2; Mar-Apr, 2021
Journal Home Page Available: https://ijels.com/
Journal DOI: $10.22161 /$ ijels

\title{
Agility Social Innovation in an Islamic Perspective: A Literature Review
}

\author{
Mufti Agung Wibowo ${ }^{1}$, Widodo ${ }^{1}$, Moch. Zulfa ${ }^{1}$
}

Faculty of Economics, Department of Management, Sultan Agung Islamic University, Indonesia

Received: 14 Dec 2020; Received in revised form: 11 Feb 2021; Accepted: 03 Mar 2021; Available online: 31 Mar 2021

C2021 The Author(s). Published by Infogain Publication. This is an open access article under the CC BY license

(https://creativecommons.org/licenses/by/4.0/).

\begin{abstract}
Social innovation intersects with social interactions that must be aligned, for the implementation of new ideas and meeting common goals for generations. Social innovation introduces a new product, program or process that changes the basic routine, the flow of resources from the social system where innovation occurs. This study builds a new conceptual model from an Islamic perspective: tawazun values, balanced or balanced thinking in all things, which encourages thinking, produces something new that encourages innovation. The tawazun mind-set maintains faith in the Creator, develops science and society as a form of gratitude for the favors of reason in the form of thought patterns, attitude patterns, action patterns, as a gift from the Almighty, to improve the quality of human life.
\end{abstract}

Keywords - Sensuous Learning Organization, Agility, Social Innovation, Organizational Performance, Islamic Perspectives.

\section{INTRODUCTION}

Dynamic Capability Theory is the capacity of an organization to create, modify or expand its resource base (Helfat, Mitchell et al. 2007), which in recent years has received high attention by management scientists (Barreto 2009). Dynamic capabilities in the organization are maintained through a process of sensing, responding, and reconfiguring and managing assets, which take place in individuals and teams, whereas sensing refers to sensing opportunities before they occur and identifying competitive threats (Teece, Peteraf et al. 2016) Based on Westley and Antadze (2010), Social innovation is a complex process of introducing new products, programs or new processes that profoundly change the basic routines, flows of resources and authority, or beliefs of the social system in which innovation occurs. Such successful social innovation has far-reaching endurance and impact. Meanwhile Nicholls, Simon et al. (2015) describes social innovation as how interpersonal activities should be organized, or social interactions, to fulfill common goals for the generation and implementation of new ideas. Social innovation, which consists of concepts and understanding, is needed to address social needs and challenges, resources, capabilities and constraints, governance, networks, actors and process dynamics (Howaldt, Oeij et al. 2016), which in its implementation requires agility. As for agility, it is defined variously in the various existing literatures Teece, Peteraf et al. (2016), the conceptual agility focuses on the company's sensing and responding capabilities (Overby, Bharadwaj et al. 2006), where the Agility Organization can be divided into two different complementary dimensions: Sensing Capability (SC) and Responsive Capability (RC) (Overby, Bharadwaj et al. 2006, Rima Zitkiene 2018), who adopted the scale (Kisperska-Moron and Swierczek 2009), where a company can be agile in customer-based processes, supply chain partner interactions and in day-to-day operations (Roberts and Grover 2012), which has the ability to strategic sensitivity, leadership unity and resource fluidity (Doz, 2008).

Based strategic capabilities Teece, Peteraf et al. (2016) cannot be separated from organizational agility, where Organizational Agility is defined as a dynamic ability in sensing (the ability to identify, develop an assessment of technological opportunities and threats related to customer needs) and capture (mobilization of resources to meet 
needs, capture values and opportunities) and transformation (continuing update or change). Overby, Bharadwaj et al. (2006) argued that organizational agility is the organization's ability to sense and respond, namely sensing environmental changes, market competition opportunities and developing conditions. The same thing was conveyed by Rima Zitkiene (2018) that organizational agility is the ability to sense and respond. The ability of social innovation is expected to have a role in developing innovative performance that can lead to continuous improvement in organizational performance.

Study results Pedler and Burgoyne (2017) found that, if firms were more performance-oriented, learning was unlikely, given that this was defined as a short-term view. While in the study Pokharel and Ok Choi (2015) shows a positive relationship between organizational learning and organizational performance. Meanwhile, Huhtala, Sihvonen et al. (2015) found evidence that to achieve high performance, public sector organizations must be more innovative. Meanwhile, Kanani (2016) stated that agility is a new method of responding to organizational change and development, but in fact there is a lack of organizational ability to rapidly penetrate new product (service) changes and is needed to regulate organizational agility. According to Zhou, Zhou et al. (2017), there is still limited literature that discusses the relationship between dynamic capabilities and different types of innovation, and how the innovation dimension can affect organizational performance.

\section{LITERATURE REVIEW}

\subsection{Sustainable Organizational Performance}

The literature reports that the competitive advantage results in organizational performance are influenced by resources. One of the resources is innovation capability, which is to capture new ideas for organizational performance. Innovation plays a key role in improving organizational performance, in terms of generating new, rare, valuable and inimitable company resources that are difficult to replicate, leading to the enrichment of corporate strategic resources and sustainable competitive advantage as important aspects of organizational performance (Samad 2012).

Performance and achievements of public sector organizations, according to Azmi and Suradi (2019) highly dependent on the level of innovation, where measurement of organizational performance refers to measuring organizational achievement. According to Huhtala, Sihvonen et al. (2015), there is an evidence that innovation is more effective when there is an increase in economic performance, so to achieve high performance, public sector organizations must be more innovative. While Zhou, Zhou et al. (2017) more specifically, the existing literature has not addressed the relationship between dynamic capabilities and different types of innovation, and how different types of innovation can affect organizational performance.

Table 1. Dimension of Organizational Performance

\begin{tabular}{|c|c|}
\hline Author & $\begin{array}{c}\text { Dimension of Organizational } \\
\text { Performance }\end{array}$ \\
\hline $\begin{array}{l}\text { Noruzy, Dalfard, } \\
\text { Azhdari, Nazari- } \\
\text { Shirkouhi, and } \\
\text { Rezazadeh (2013) }\end{array}$ & $\begin{array}{ll}\text { - } & \text { Profitability or profit } \\
\text { - } & \text { Sales growth } \\
\text { - } & \text { Customer satisfaction } \\
\text { - } & \text { Overall performance. }\end{array}$ \\
\hline Choi and Yu (2014) & $\begin{array}{ll}\text { - } & \text { Growth and sales } \\
\text { - } & \text { Market value } \\
\text { - } & \text { Efficiency } \\
\text { - } & \text { Cost savings }\end{array}$ \\
\hline $\begin{array}{l}\text { Singh, Darwish, and } \\
\text { Potočnik (2016) }\end{array}$ & $\begin{array}{ll}- & \text { Profitability (after tax) } \\
\text { - } & \text { Sales revenue } \\
\text { - } & \text { Stock } \\
\text { - } & \text { Innovation }\end{array}$ \\
\hline
\end{tabular}

\subsection{Social Innovation}

Social theory according to Gabriel Tarde (1985) is a social innovation concept based on sociological theory and practice (Howaldt, Oeij et al. 2016). Macro phenomena, for Tarde, such as social structures, systems and social changes, are things that are difficult to explain, considering that complexity actually lies in microphenomena. Tarde's contribution to microfoundation in terms of the sociology of innovation and developing the concept of social innovation as a mechanism for social change at the micro and meso levels (Mayntz 2016). Invention and imitation for Tarde are two key elements in the concept of innovation based on sociological aspects. Invention, through imitation, becomes an innovation, so that discovery and imitation are key elements in the cumulative evolution of culture, becoming social facts specific to society (Lohmann H 2003).

The dimensions of social innovation according to Andre and Abreu (2006) includes basic characteristics, stimuli, resources and dynamics, agency relationships, creative and 
innovative means; Meanwhile Nicholls, Simon et al. (2015) states that the dimensions of social innovation include individuals, organizations, networks / movements and systems; and Howaldt, Oeij et al. (2016) complementing the dimensions of social innovation consisting of concepts and understanding, addressing social needs and challenges, resources, capabilities and constraints, governance, networks, actors and process dynamics. Innovation is a complex construct; various individual, organizational and contextual factors influence its application. Innovations of various kinds influence and often complement each other. A balanced level of adoption of administrative and technical innovations is more effective in helping an organization increase its level of performance than administrative or technical innovations (Honyenuga 2019).

Innovative performance, refers to the organization's innovative efforts towards products, processes and improvement of the organizational structure, where according to Quandt and Castilho (2017), Innovative performance is linked to the dimensions that provide the conditions for and enable innovation: strategy, organizational structure, leadership, networks, culture, processes, people, relationships, technological infrastructure, measurement and learning.

Governments are increasingly engaging private sector organizations, civil society and citizens to address complex policy challenges through several forms of network governance arrangements. Governance networks generally facilitate flexibility, speed and innovation in governance, necessary to meaningfully organize smart societies that are characterized by a multitude of programs spanning policy domains and levels of government (Krucken and Meroni 2006, Ojo and Mellouli 2018).

For organizations that wish to survive and thrive, speed and innovation are imperative; across sectors there are calls for organizational agility. Agility is the organizational capacity to perceive, respond, adapt quickly, and develop in a changing environment (Holbeche 2018).

Table 2. Dimension of Social Innovation.

\begin{tabular}{|c|c|}
\hline Author & Dimension of Social Innovation \\
\hline \multirow{5}{*}{$\begin{array}{l}\text { Andre and } \\
\text { Abreu } \\
\text { (2006): }\end{array}$} & Nature, natural \\
\hline & - incentive \\
\hline & - $\quad$ Resources and dynamics \\
\hline & - $\quad$ Agency relationship \\
\hline & - $\quad$ Creative and innovative \\
\hline
\end{tabular}

Nicholls and - Individual

$\begin{array}{lll}\text { Murdock } & - & \text { Organization } \\ (2012) & - & \text { Networking / movement } \\ & - & \text { System }\end{array}$

Boelman _ - Framework conditions.

and Heales - Organizational Output and social (2015) impact.

- Entrepreneurial activities that result in social innovation.

Howaldt, - Concepts and understanding.

Oeij,

Dhondt, and

Fruytier

(2016)

- Addressing social needs and challenges.

- Resources, capabilities and constraints.

- Governments, networks, actors.

- Process dynamics.

$\begin{array}{llll}\text { Souza, } & - & \text { Transformation } \\ \text { Lessa, and } & & \text { Novelty } \\ \text { Lázaro da } & & \text { Innovation } \\ \text { Silva Filho } & - & \\ (2019) & & - & \text { Actor } \\ & & - & \text { Process Proses }\end{array}$

\subsection{Sensuous Learning Organization}

The new learning organization is known as the sensuous learning organization, not only overcoming professional disabilities, but also advancing quality (Antonacopoulou and Taylor 2019). New Organizational Learning played out in response to VUCA (Flexibility, Uncertainty, Complexity and Ambiguity) (Bennett and Lemoine 2014), conditions with the VUCA approach to high agility organizations, innovation and leadership learning that foster institutional reflection.

While learning remains an active process that reshapes both knowing and responding, agility is an ongoing adaptation to action. Sensuous Organizational Learning (reflected in values - attention, vigilance, awareness, appreciation, anticipation, harmony, activation and agility), as an integral step to meet VUCA conditions, coexist and embrace crises in learning to determine direction of action (Antonacopoulou and Sheaffer 2014).

Innovation and organizational learning, according to Nawaz and Koç (2018) needed in capacity building towards a sustainable organizational transition. Employee experience and skills influence the integration of new knowledge into organizational processes, which leads to 
innovation and increased organizational strength by providing the ability to cope with emerging challenges (Asif, Svensson et al. 2011).

\subsection{Social innovation in an Islamic perspectives.}

In the Islamic view, this argument related to innovation is contained in QS. ar-Ra'd (13): 11, ".. Allah does not change the condition of a people so that they change the condition that is in themselves." (Surah ar-Ra'd: 11). This means that human beings must endeavor to change their own situation for the better, one of which is through renewal or innovation. In another verse, tawazun or balanced thinking is also present in QS. Al-Furqan: 67, which means "And people who when they spend (wealth), they are not excessive, and are not (also) stingy, and are (the spending) in the middle of that". The principle of tawazun or balance is not only related to the interests of the world and the hereafter, but is closely related to social interests that must be maintained,

Agility Social Innovation in Islamic view is the agility of social innovation ability which has balance values (tawazun) which is rooted in the idea of social sensing ability, dynamic response ability, digital sensing ability and network response ability that triggers an increase in organizational performance through measuring values of benefit, empowerment and mutual cooperation in social responsibility, as well as the benefit to the environment and the people. Based on the description above, the following proposition is proposed:

\section{Proposition:}

Agility social innovation moderates sensuous organizational learning, realizing sustainable organizational performance.

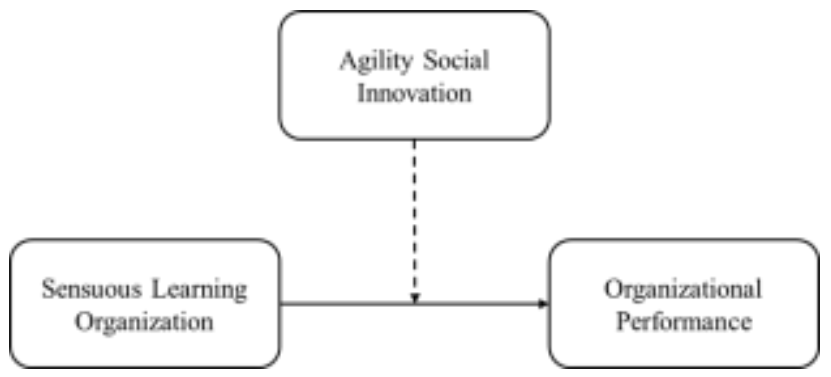

Fig. 1: Conceptual model of agility social innovation.

\section{METHOD}

Literature review is based on content analysis related to organizing, categorizing, and coding. The analysis of the adopted literature related to the study is shown in Table 3 .

Table 3. Literature review adoption procedures.

\begin{tabular}{ll}
\hline Aims & $\begin{array}{l}\text { Identification of scientific publications } \\
\text { with the } \\
\text { performance, organizational learning, and } \\
\text { social innovation agility. }\end{array}$ \\
\hline Scope & Scopus, Google Scholar \\
\hline $\begin{array}{l}\text { Search } \\
\text { terms }\end{array}$ & $\begin{array}{l}\text { "organizational performance"; "Learning } \\
\text { organization"; "Social agility innovation" }\end{array}$ \\
\hline $\begin{array}{l}\text { Inclusion } \\
\text { criteria }\end{array}$ & $\begin{array}{l}\text { Articles are taken from search and archive } \\
\text { of articles related to the topic. }\end{array}$ \\
\hline $\begin{array}{l}\text { Exclusion } \\
\text { criteria }\end{array}$ & $\begin{array}{l}\text { Articles published in languages other than } \\
\text { English }\end{array}$ \\
\hline
\end{tabular}

\section{CONCLUSION}

This study contributes to Dynamic Ability Theory, namely agility, and to Sociological Theory, namely social innovation in an Islamic perspective: Tawazun based on New Organizational Learning so as to realize sustainable organizational performance and innovative performance. There are several limitations, empirical testing of the conceptual model and a varied literature review that can provide opportunities for future research.

\section{ACKNOWLEDGEMENTS}

Authours would like to acknowledge to thank very much the Central Java provincial government, Indonesia, and Department of Management, Sultan Agung Islamic University, Semarang, Indonesia.

\section{REFERENCES}

[1] Alex Nicholls, J. S. a. M. G. (2015). "Introduction: Dimensions of Social Innovation." Research in Social Innovation: 26.

[2] Alzuod, M. A. K., et al. (2017). "Intellectual Capital_Innovative Performance and the Moderating Effect of Entrepreneurial Orientation SME."

[3] Andre, I. and A. Abreu (2006). "DIMENSÕES E ESPAÇOS DA INOVAÇÃO SOCIAL." 21.

[4] Antonacopoulou, E. P. (2018). "Organisational Learning for and with VUCA: Learning Leadership Revisited."

[5] Antonacopoulou, E. P., et al. (2019). "The New Learning Organisation PART I - Institutional Reflexivity, High Agility Organizing n learning leadership."

[6] Antonacopoulou, E. P. and Z. Sheaffer (2014). "Learning in Crisis RETHINKING ORGANISATIONAL LEARNING IN RELATION TO CRISIS MANAGEMENT."

[7] Antonacopoulou, E. P. and S. S. Taylor (2019). "Sensuous Learning for Practical Judgment."

[8] Asif, M., et al. (2011). "An integrated management systems approach to corporate sustainability." European Business Review 23(4): 353-367. 
[9] Azmi, R. and N. R. M. Suradi (2019). "Innovation Capability and Organization Performance in Malaysia Public Sector."

[10] Barreto, I. (2009). "Dynamic Capabilities: A Review of Past Research and an Agenda for the Future." Journal of Management 36(1): 256-280.

[11] Bennett, N. and G. J. Lemoine (2014). "What a difference a word makes: Understanding threats to performance in a VUCA world." Business Horizons 57(3): 311-317.

[12] Boelman, V. and C. Heales (2015). "Social Innovation DRIVE Global Region Report."

[13] Doz, Y. a. K., Mikko (2008). "The Dynamics of Strategic Agility-Nokia Rollercoaster Experience.pdf."

[14] Helfat, C. E., et al. (2007). "Dynamic Capabilities Understanding Strategic Change in Organizations."

[15] Helfat, C. E. and M. A. Peteraf (2015). "Managerial cognitive capabilities and the microfoundations of dynamic capabilities." Strategic Management Journal 36(6): 831850.

[16] Holbeche, L. S. (2018). "Organisational effectiveness and agility." Journal of Organizational Effectiveness: People and Performance 5(4): 302-313.

[17] Honyenuga, B. Q. (2019). "management innovation and organisational performance-mediating organisational framework."

[18] Howaldt, J., et al. (2016). "Workplace innovation and social innovation: an introduction." World Review of Entrepreneurship, Management and Sustainable Development 12(1): 1.

[19] Huhtala, J.-P., et al. (2015). "Market orientation innovation capability and business performance."

[20] Kanani, N. (2016). "Analysis of factors affecting organizational agility."

[21] Kisperska-Moron, D. and A. Swierczek (2009). "The agile capabilities of Polish companies in the supply chain: An empirical study." International Journal of Production Economics 118(1): 217-224.

[22] Lohmann H, T. (2003). "Language and Social Understanding: Commentary on Nelson et al. ."

[23] Mack, O. and A. Khare (2016). "Perspectives on a VUCA World." 3-19.

[24] Mayntz, R. (2016). "Mechanisms in the Analysis of Social Macro-Phenomena." Philosophy of the Social Sciences 34(2): 237-259.

[25] Nawaz, W. and M. Koç (2018). "Development of a systematic framework for sustainability management of organizations." Journal of Cleaner Production 171: 12551274.

[26] Nicholls, A. and A. Murdock (2012). "he Nature of Social Innovation."

[27] Overby, E., et al. (2006). "Enterprise agility and the enabling role of information technology." European Journal of Information Systems 15(2): 120-131.

[28] Pedler, M. and J. G. Burgoyne (2017). "Is the learning organisation still alive?" The Learning Organization 24(2): 119-126.

[29] Pokharel, M. P. and S. Ok Choi (2015). "Exploring the relationships between the learning organization and organizational performance." Management Research Review 38(2): 126-148.

[30] Richard L. Daft, w. t. a. o. P. G. L. (2010). "Organization Theory and Design_10Ed."

[31] Rima Zitkiene, M. D. (June 2018). "Organizational Agility Conceptual Model." Montenegrin Journal of Economics 14: 115-129

[32] Roberts, N. and V. Grover (2012). "Investigating firm's customer agility and firm performance: The importance of aligning sense and respond capabilities." Journal of Business Research 65(5): 579-585.

[33] Samad, S. (2012). "The Influence of Innovation and Transformational Leadership on Organizational Performance." Procedia - Social and Behavioral Sciences 57: 486-493.

[34] Souza, A. C. A. A. d., et al. (2019). "Social innovation and the promotion of local economic development." Innovation \& Management Review 16(1): 55-71.

[35] Souza, T. A. d., et al. (2019). "Innovative performance of Brazilian public higher educational institutions." Innovation \& Management Review 16(4): 323-343.

[36] Teece, D., et al. (2016). "Dynamic capabilities and organizational agility: Risk, uncertainty, and strategy in the innovation economy." California Management Review, $\underline{58(4)}$.

[37] Westley, F. and N. Antadze (2010). "Making a Difference Strategies for Scaling Social Innovation for Greater Impact."

[38] Zhou, S. S., et al. (2017). "Dynamic capabilities and organizational performance: The mediating role of innovation." Journal of Management \& Organization 25(5): 731-747.

[39] Overby, E., Bharadwaj, A., Sambamurthy, V. (2005), "Business Agility and Information Technology Diffusion", international conference proceedings: A Framework for Enterprise Agility and the Enabling Role of Digital Options, Atlanta: Georgia pp. 295-312. 